\title{
Unpredictable cycloisomerization of 1,11-dien-6-ynes by a common cobalt catalyst
}

\author{
Abdusalom A. Suleymanov, Dmitry V. Vasilyev, Valentin V. Novikov, Yulia V. Nelyubina \\ and Dmitry S. Perekalin*
}

\author{
Full Research Paper \\ Address: \\ Nesmeyanov Institute of Organoelement Compounds, Russian \\ Academy of Sciences, 28 Vavilova str., 119991, Moscow, Russian \\ Federation \\ Email: \\ Dmitry S. Perekalin* - dsp@ineos.ac.ru \\ * Corresponding author \\ Keywords: \\ catalysis; cobalt; cyclization; enynes; ligands
}

\author{
Beilstein J. Org. Chem. 2017, 13, 639-643. \\ doi:10.3762/bjoc. 13.62 \\ Received: 24 January 2017 \\ Accepted: 15 March 2017 \\ Published: 31 March 2017 \\ Associate Editor: K. Itami \\ (C) 2017 Suleymanov et al.; licensee Beilstein-Institut. \\ License and terms: see end of document.
}

\begin{abstract}

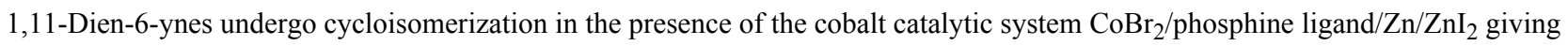
cyclohexene, diene or cyclopropane structures depending on the type of the phosphine ligand. This unpredictable behaviour suggests that, although the availability of the cobalt catalytic system is appealing, the development of well-defined catalysts is desirable for further progress.
\end{abstract}

\section{Introduction}

Metal-catalyzed reactions of enynes represent an atom- and step-economical route to complex organic molecules with a broad range of functionalities [1-4]. In particular, cycloisomerization of enynes allows one to prepare compounds with exocyclic double bonds and cyclopropanes in a highly selective manner [5-7]. While catalytic transformations of enynes have been investigated in detail, there are only a few examples of similar reactions of dienynes [8-14]. Among dienynes, 1,11dien-6-ynes 1 are of particular interest, because they are readily available in 1-2 steps from the commercial precursors (e.g., allyl bromides and 1,4-dibromo-2-butyne). Transformations of 1,11-dien-6-ynes provide an access to highly substituted poly- cycles [8,11-13] (Scheme 1). However, all these transformations require expensive noble metal catalysts with rather sophisticated ligands. Therefore, the development of a cheap catalyst for such reactions is highly desirable.

Over the last decade the application of the cobalt catalytic system $\mathrm{CoBr}_{2} /$ phosphine ligand/Zn/ZnI 2 for the carbon-carbon bond formation has become a subject of a growing interest (for reviews see [15-21]). This catalytic system has many advantages, including the availability of the cobalt salts and high tolerance to organic functional groups (for some recent examples see [22-27]). However, it has been noted that the direction 


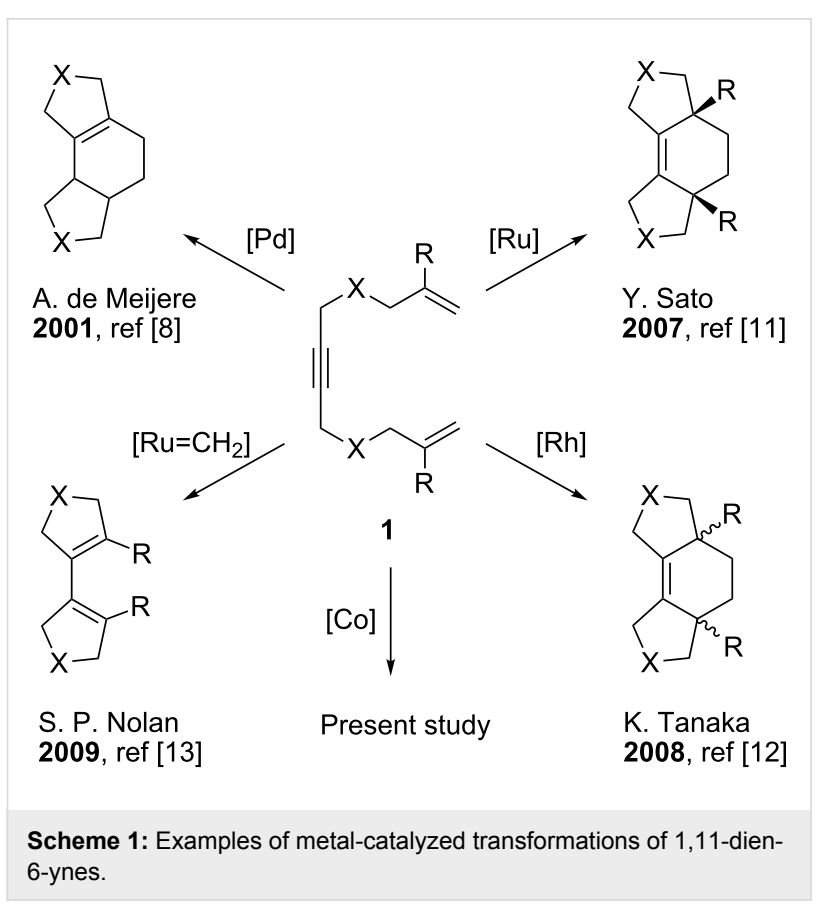

of the catalytic reactions often depends on the structure of the phosphine ligand. Major research on these ligand-controlled reactions has been made by the groups of Hilt and Cheng, in particular, on the selective formation of metalpara-products of Diels-Alder reactions [28-32], linear/branched products of hydrovinylation reactions [33,34], [2 +2] cycloadditions vs Alder-ene reactions [35], E/Z isomerizations of alkenes [36,37] and other processes [38-42].

Herein, we report the cycloisomerizations of 1,11-dien-6-ynes in the presence of a cobalt catalytic system. We have found that the regioselectivity of these reactions dramatically and unpredictably depends on the structure of the phosphine ligand and on the structure of the substrate.

\section{Results and Discussion}

First, we chose 1,4-bis(allyloxy)but-2-yne (1a) and 1,4-di( $N$ allyltosylamido)-2-butyne (1b) as test substrates for our investigation (Scheme 2). It was found that in the presence of $\mathrm{CoBr}_{2}$, $\mathrm{Zn}$ and $\mathrm{ZnI}_{2}$ (20 mol \% each) as well as the triphenylphosphine ligand $(40 \mathrm{~mol} \%)$ in 1,2-dichloroethane (DCE) these substrates underwent clean $[2+2+2]$-cyclotrimerization to give cyclohexene derivatives $\mathbf{2 a}, \mathbf{b}$ in $70-90 \%$ yields. The rate of the reaction notably varied from experiment to experiment, but full conversion of $\mathbf{1} \mathbf{a}, \mathbf{b}$ into $\mathbf{2 a}, \mathbf{b}$ was usually achieved after $24 \mathrm{~h}$. Attempts to employ $10 \mathrm{~mol} \%$ loading of the pre-catalysts often led to incomplete conversion. Apparently, because of the heterogeneous nature of the mixture, only a small fraction of the cobalt salt actually formed the catalytically active species. Moreover, we found that it was important to activate the $\mathrm{Zn} /$
$\mathrm{ZnI}_{2}$ mixture prior addition of the substrate either by heating or by generation of $\mathrm{ZnI}_{2}$ in situ from the excess of $\mathrm{Zn}$ and $\mathrm{I}_{2}$. Variation of the solvent (MeCN, THF, DCE) and the reaction temperature $\left(20-80^{\circ} \mathrm{C}\right)$ had no significant influence on the reaction outcome.

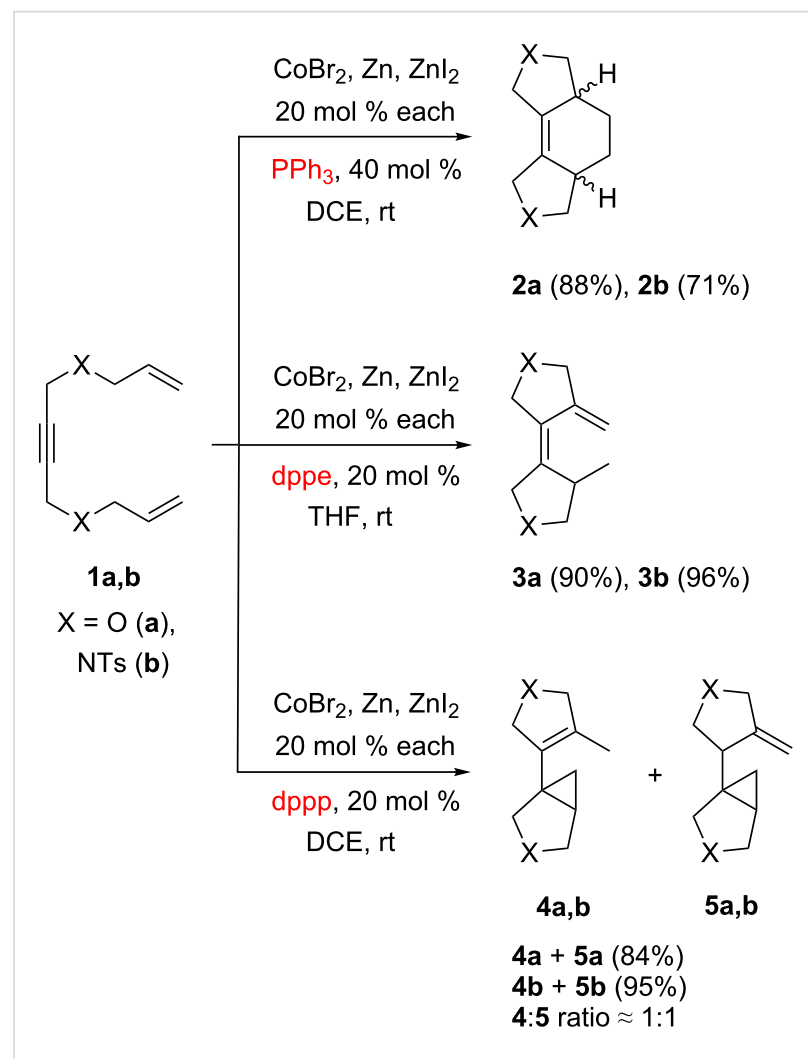

Scheme 2: Cobalt-catalyzed cycloisomerizations of 1,11-dien-6-ynes.

Although the yields of $\mathbf{2 a}, \mathbf{b}$ were good, the compounds were formed as roughly 1:1 mixtures of cis- and trans-isomers (cisisomers were reported previously [11] which helped us to assign the structures of $\mathbf{2 a}, \mathbf{b})$. In attempt to improve the selectivity we used 1,2-bis(diphenylphosphino)ethane (dppe) as ligand instead of $\mathrm{PPh}_{3}$. However, this ligand completely changed the direction of the cyclization, converting $\mathbf{1 a}, \mathbf{b}$ into the diene compounds $\mathbf{3 a}$, b in $90-95 \%$ yields. These compounds were also obtained using a 1,2-bis(diphenylphosphino)benzene (dppbz) ligand. Despite the extensive studies of enyne transformations, this type of cyclization has been achieved only recently, using a cyclobutadiene rhodium complex as a catalyst [43].

Next, we employed 1,3-bis(diphenylphosphino)propane (dppp) as a phosphine ligand, which surprisingly led to conversion of $\mathbf{1}$ into some new isomeric products. The ${ }^{1} \mathrm{H}$ NMR spectra of these products contained a number of signals in the $0.5-0.8 \mathrm{ppm}$ region, which is characteristic for cyclopropane protons. On the 
basis of ${ }^{1} \mathrm{H}-{ }^{1} \mathrm{H}$ and ${ }^{1} \mathrm{H}-{ }^{13} \mathrm{C}$ correlation NMR spectra as well as GC-MS analysis we had assigned the structures of these products as the cyclopropane derivatives with internal 4 and exocyclic 5 double bonds (Scheme 2). Our spectral data correlate well with that of similar compounds, which were recently prepared by the rhodium-catalyzed cyclopropanation [44]. Compounds $\mathbf{4}$ and $\mathbf{5}$ were obtained as mixtures with approximately $1: 1$ ratio and total $80-90 \%$ yields. Numerous attempts to convert 5 into the more stable isomer $\mathbf{4}$ using strong bases or transition metal catalysts were unsuccessful. The cobalt catalytic system with other phosphine ligands, such as dppm, dppf, or BINAP, did not catalyze cycloisomerization of $\mathbf{1}$ into any products.

In order to explain the formation of products $\mathbf{2}-\mathbf{5}$ we proposed a possible mechanism (Scheme 3) in accordance with the generally accepted concepts $[15,18]$. The crucial step of this mechanism is the formation of metallacycle 6 from unsaturated cobalt(I) species $\left[\mathrm{Co}\left(\mathrm{PR}_{3}\right)_{2} \mathrm{Br}\right]$ and the double and the triple bond of dienyne 1 (see Supporting Information File 1 for the calculated structure of $\mathbf{6}$ ). Subsequent insertion of the double bond into the $\mathrm{Co}-\mathrm{C}$ bond of 6 leads to the 7-membered metallacycle 7 , which can undergo reductive elimination to give the cyclohexene 2 , or $\beta$-hydride elimination followed by the reductive elimination to give the diene $\mathbf{3}$. It may be speculated that the steric crowding in the intermediate 7 determines the direction of the reaction. In contrast to the relatively small dppe ligand, two large $\mathrm{Ph}_{3} \mathrm{P}$ ligands hinder the $\beta$-elimination (which requires proximal syn-position of metal and hydrogen) and therefore push reaction towards direct reductive elimination to give 2 .

Alternatively, $\beta$-hydride elimination can proceed in the intermediate 6 to give the hydride species 8 . Further, intramolecular 1,2- or 1,4-hydrometallation in $\mathbf{8}$ produces carbene complexes, which give cyclopropane derivatives $\mathbf{4}$ and $\mathbf{5}$.

In order to broaden the substrate scope, we studied similar reactions of the tetramethyl-substituted dienyne 1c (Scheme 4). As expected, it produced the cyclohexene derivative $2 \mathbf{c}$ in the presence of the triphenylphosphine ligand. More surprisingly, the same product was obtained when dppe or dppp were used as

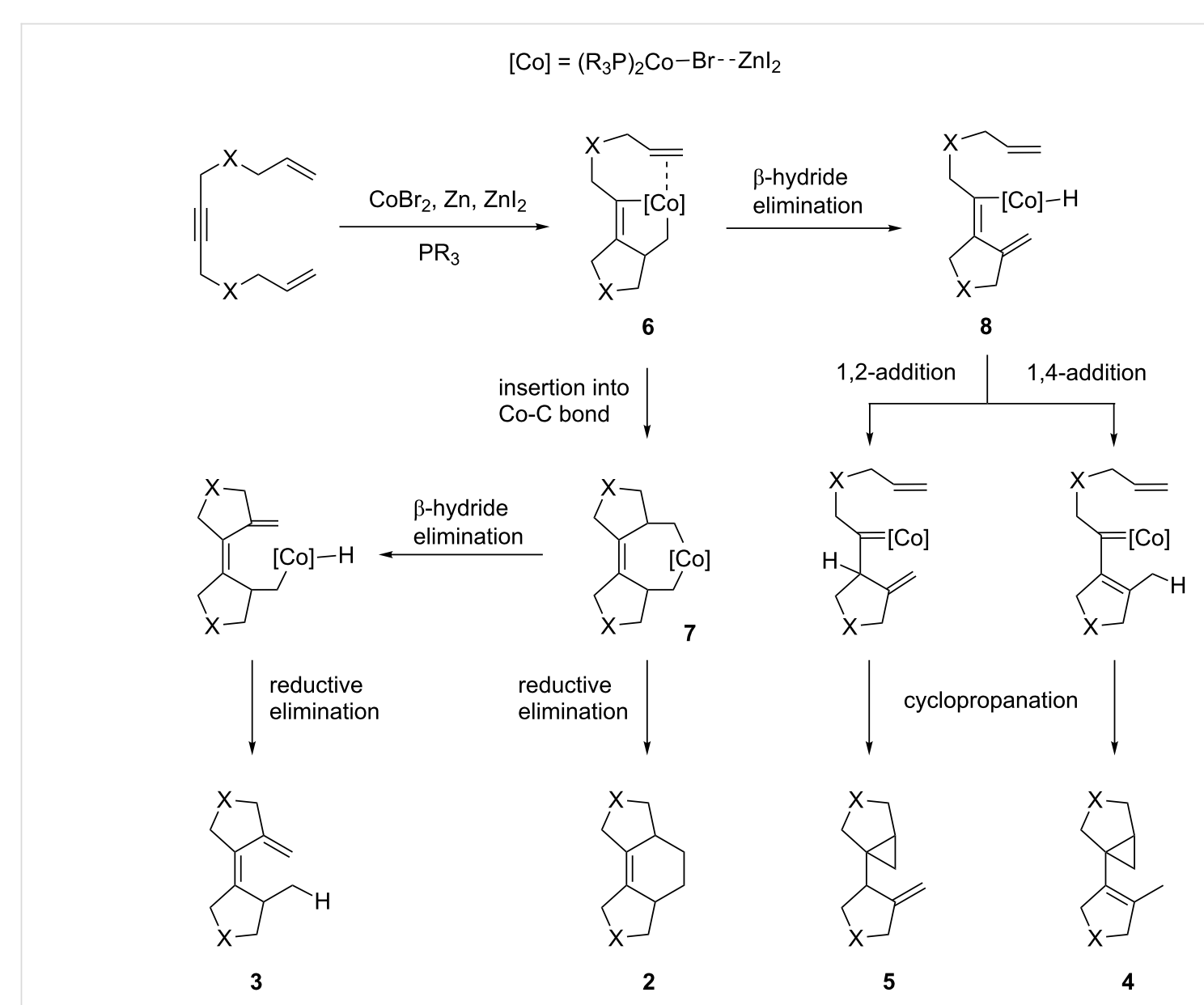

Scheme 3: Possible mechanism for formation of the compounds 2-5. 
ligands, although the small amounts of isomeric by-products were detected in these cases. Noteworthy, according to the NMR spectra, product $\mathbf{2 c}$ was formed as a single diastereomer, however, it was not possible to unambiguously determine whether it was the cis- or the trans-isomer by NMR (including various correlation techniques) because of the high symmetry of both possible isomers. Attempts to grow crystals of $\mathbf{2 c}$ or its $\mathrm{Br}_{2}$ adduct for X-ray crystallography were also unsuccessful.

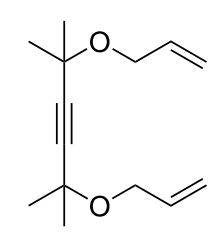

$1 \mathrm{c}$

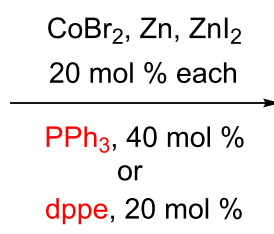

DCE, rt

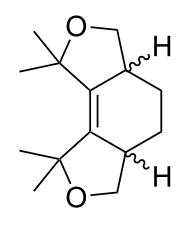

2c $(92 \%)$
Scheme 4: Cycloisomerization of the substituted dienyne 1c.

Further experiments have shown that many other 1,11-dien-6ynes 1d-l (Figure 1) did not undergo cycloisomerization in the presence of the cobalt catalytic system regardless of the employed ligand. In the case of the substrates $\mathbf{1 d - h}$ this may be explained by the increased steric crowding, which is evident from the $3 \mathrm{D}$ structure of the proposed intermediate $\mathbf{6}$ (see Supporting Information File 1). In the case of $\mathbf{1} \mathbf{i}-\mathbf{k}$ the electron acceptor effects or the restricted rotation of conjugated enones could be the problem. The case of dienyne $\mathbf{1 l}$ was particularly surprising as it seemed to have a very similar structure to that of $\mathbf{1 a}, \mathbf{b}$. We can speculate that COOEt groups of $\mathbf{1 1}$ formed a chelate complex with $\mathrm{ZnI}_{2}$ and therefore strongly diminished its Lewis acidity, which is necessary for catalyst activation.

All the compounds obtained were characterized by ${ }^{1} \mathrm{H}$ and ${ }^{13} \mathrm{C}$ NMR spectroscopy as well as high-resolution mass-spectrometry (for ethers, which are oils) or elemental analysis (for tosylamides, which are crystalline solids). The structures of the starting dienyne $\mathbf{1 h}$ and the cyclohexene trans-2b were established by X-ray crystallography. The structures of cis-2b and $\mathbf{3 b}$ had been reported previously $[11,43]$.

\section{Conclusion}

To conclude, we have shown that the behavior of the popular catalytic system $\mathrm{CoBr}_{2} /$ phosphine ligand/Zn/ZnI 2 is very sensitive to the structure of the phosphine ligand and to the structure of the substrate. On the one hand, this allows one to discover unusual transformations of the unsaturated substrates. On the other hand, such sensitivity hinders the development of general methods, which can be applied to a wide range of compounds. Overall, although the availability of the cobalt catalytic system<smiles>[R]C([R])(C#CC([R])([R])OCC(=C)C)OCC(=C)C</smiles><smiles>[R]C([R])(C#CC([R])([R])O[Si](C)(C)C=C)O[Si](C)(C)C=C</smiles><smiles>CC(C)=CCN([13CH3])CC#CCN([13CH3])CC=C(C)C</smiles>
$R=H(1 d), M e(1 e)$

$R=H(\mathbf{1 f}), M e(1 g)$

1h<smiles>[R]C([R])(C#CC([R])([R])OC(=O)C=C)OC(=O)C=C</smiles>

$R=H(1 \mathbf{i}), M e(1 j)$<smiles>C=CCOC(=O)C#CC(=O)OCC=C</smiles>

$1 k$<smiles>C=CCC(CC#CCC(CC#CCC(COCC)(OCC)OCC)(OCC)OCC)(OCC)OCC</smiles>

11

Figure 1: The substituted 1,11-dien-6-ynes that did not undergo cycloisomerization in the presence of the cobalt catalytic system.

is appealing, the development of a well-defined catalyst with precisely-controlled ligand environment is necessary for further progress.

\section{Supporting Information}

Experimental details and detailed spectroscopic data of all compounds are available as Supporting Information. Single crystal data for $\mathbf{1 h}$ and $\mathbf{2 b}$ (CCDC 1516680 and 1516681) has been deposited in the Cambridge Crystallographic Data Center.

\section{Supporting Information File 1}

Experimental details and detailed spectroscopic data of all compounds.

[http://www.beilstein-journals.org/bjoc/content/ supplementary/1860-5397-13-62-S1.pdf]

\section{Supporting Information File 2}

Single crystal data for $\mathbf{1 h}$ and $\mathbf{2 b}$.

[http://www.beilstein-journals.org/bjoc/content/ supplementary/1860-5397-13-62-S2.zip]

\section{Acknowledgements}

This work was supported by the Russian Foundation for Basic Research (grant 16-33-00948) and the Council of the President of the Russian Federation (grant for young scientists MK-6254.2016.3). 


\section{References}

1. Michelet, V.; Toullec, P. Y.; Genêt, J.-P. Angew. Chem., Int. Ed. 2008, 47, 4268. doi:10.1002/anie.200701589

2. Jiménez-Núñez, E.; Echavarren, A. M. Chem. Rev. 2008, 108, 3326. doi:10.1021/cr0684319

3. Domínguez, G.; Pérez-Castells, J. Chem. Soc. Rev. 2011, 40, 3430. doi:10.1039/c1cs15029d

4. Domínguez, G.; Pérez-Castells, J. Chem. - Eur. J. 2016, 22, 6720. doi:10.1002/chem.201504987

5. Bruneau, C. Angew. Chem., Int. Ed. 2005, 44, 2328. doi:10.1002/anie.200462568

6. Inglesby, P. A.; Evans, P. A. Chem. Soc. Rev. 2010, 39, 2791. doi:10.1039/b913110h

7. Amatore, M.; Aubert, C. Eur. J. Org. Chem. 2015, 265. doi:10.1002/ejoc.201403012

8. van Boxtel, L. J.; Körbe, S.; Noltemeyer, M.; de Meijere, A. Eur. J. Org. Chem. 2001, 2283. doi:10.1002/1099-0690(200106)2001:12<2283::AID-EJOC2283>3.0.C O;2-G

9. Himes, R. A.; Fanwick, P. E.; Rothwell, I. P. Chem. Commun. 2003, 18. doi:10.1039/B209889J

10. Shibata, T.; Tahara, Y.-k. J. Am. Chem. Soc. 2006, 128, 11766. doi:10.1021/ja0639160

11. Tanaka, D.; Sato, Y.; Mori, M. J. Am. Chem. Soc. 2007, 129, 7730. doi:10.1021/ja071954t

12. Sagae, H.; Noguchi, K.; Hirano, M.; Tanaka, K. Chem. Commun. 2008, 3804. doi:10.1039/b804294b

13. Clavier, H.; Correa, A.; Escudero-Adán, E. C.; Benet-Buchholz, J.; Cavallo, L.; Nolan, S. P. Chem. - Eur. J. 2009, 15, 10244. doi:10.1002/chem.200900976

14. Saito, N.; Tanaka, D.; Mori, M.; Sato, Y. Chem. Rec. 2011, 11, 186 doi:10.1002/tcr.201100003

15. Jeganmohan, M.; Cheng, C.-H. Chem. - Eur. J. 2008, 14, 10876. doi:10.1002/chem.200800904

16. Hess, W.; Treutwein, J.; Hilt, G. Synthesis 2008, 3537. doi:10.1055/s-0028-1083210

17. Cahiez, G.; Moyeux, A. Chem. Rev. 2010, 110, 1435. doi:10.1021/cr9000786

18. Gao, K.; Yoshikai, N. Acc. Chem. Res. 2014, 47, 1208. doi:10.1021/ar400270x

19. Pellissier, H.; Clavier, H. Chem. Rev. 2014, 114, 2775. doi:10.1021/cr4004055

20. Gandeepan, P.; Cheng, C.-H. Acc. Chem. Res. 2015, 48, 1194. doi:10.1021/ar500463r

21. Röse, P.; Hilt, G. Synthesis 2016, 463. doi:10.1055/s-0035-1560378

22. Saino, N.; Amemiya, F.; Tanabe, E.; Kase, K.; Okamoto, S. Org. Lett. 2006, 8, 1439. doi:10.1021/ol0602295

23. Sakurada, T.; Sugiyama, Y.-k.; Okamoto, S. J. Org. Chem. 2013, 78, 3583. doi:10.1021/j0400064b

24. Geny, A.; Gaudrel, S.; Slowinski, F.; Amatore, M.; Chouraqui, G.; Malacria, M.; Aubert, C.; Gandon, V. Adv. Synth. Catal. 2009, 351, 271. doi:10.1002/adsc. 200800646

25. Achard, M.; Tenaglia, A.; Buono, G. Org. Lett. 2005, 7, 2353. doi:10.1021/ol050618j

26. Toselli, N.; Martin, D.; Achard, M.; Tenaglia, A.; Bürgi, T.; Buono, G. Adv. Synth. Catal. 2008, 350, 280. doi:10.1002/adsc.200700424

27. Nishimura, A.; Tamai, E.; Ohashi, M.; Ogoshi, S. Chem. - Eur. J. 2014, 20, 6613. doi:10.1002/chem.201402218

28. Hilt, G.; Korn, T. J. Tetrahedron Lett. 2001, 42, 2783. doi:10.1016/S0040-4039(01)00289-1
29. Hilt, G.; Janikowski, J.; Hess, W. Angew. Chem., Int. Ed. 2006, 45, 5204. doi:10.1002/anie.200601974

30. Kuttner, J. R.; Warratz, S.; Hilt, G. Synthesis 2012, 1293. doi:10.1055/s-0031-1289752

31. Fiebig, L.; Kuttner, J.; Hilt, G.; Schwarzer, M. C.; Frenking, G.; Schmalz, H.-G.; Schäfer, M. J. Org. Chem. 2013, 78, 10485. doi:10.1021/jo402001g

32. Hilt, G.; Janikowski, J.; Schwarzer, M.; Burghaus, O.; Sakow, D.; Bröring, M.; Drüschler, M.; Huber, B.; Roling, B.; Harms, K.; Frenking, G. J. Organomet. Chem. 2014, 749, 219. doi:10.1016/j.jorganchem.2013.09.020

33. Arndt, M.; Dindaroğlu, M.; Schmalz, H.-G.; Hilt, G. Org. Lett. 2011, 13, 6236. doi:10.1021/ol202696n

34. Mannathan, S.; Cheng, C.-H. Chem. - Eur. J. 2012, 18, 11771. doi:10.1002/chem.201200779

35. Hilt, G.; Paul, A.; Treutwein, J. Org. Lett. 2010, 12, 1536. doi:10.1021/ol100266u

36. Pünner, F.; Schmidt, A.; Hilt, G. Angew. Chem., Int. Ed. 2012, 51, 1270. doi:10.1002/anie.201107512

37. Schmidt, A.; Nödling, A. R.; Hilt, G. Angew. Chem., Int. Ed. 2015, 54, 801. doi:10.1002/anie.201409902

38. Chang, H.-T.; Thiruvellore, T. J.; Wang, C.-C.; Cheng, C.-H. J. Am. Chem. Soc. 2007, 129, 12032. doi:10.1021/ja073604c

39. Wei, C.-H.; Mannathan, S.; Cheng, C.-H. J. Am. Chem. Soc. 2011, 133, 6942. doi:10.1021/ja201827j

40. Wei, C.-H.; Mannathan, S.; Cheng, C.-H. Angew. Chem., Int. Ed. 2012, 51, 10592. doi:10.1002/anie.201205115

41. Santhoshkumar, R.; Mannathan, S.; Cheng, C.-H. Org. Lett. 2014, 16, 4208. doi:10.1021/ol501904e

42. Santhoshkumar, R.; Mannathan, S.; Cheng, C.-H. J. Am. Chem. Soc. 2015, 137, 16116. doi:10.1021/jacs.5b10447

43. Perekalin, D. S.; Shvydkiy, N. V.; Nelyubina, Y. V.; Kudinov, A. R. Chem. - Eur. J. 2015, 21, 16344. doi:10.1002/chem.201503270

44. Torres, O.; Roglans, A.; Pla-Quintana, A. Adv. Synth. Catal. 2016, 358, 3512. doi:10.1002/adsc.201600789

\section{License and Terms}

This is an Open Access article under the terms of the Creative Commons Attribution License (http://creativecommons.org/licenses/by/4.0), which permits unrestricted use, distribution, and reproduction in any medium, provided the original work is properly cited.

The license is subject to the Beilstein Journal of Organic Chemistry terms and conditions: (http://www.beilstein-journals.org/bjoc)

The definitive version of this article is the electronic one which can be found at: doi:10.3762/bjoc. 13.62 